Perbaikan Kualitas Proses Produksi di UKM Keripik Singkong - Mustaniroh, dkk Jurnal Pangan dan Agroindustri Vol.8 No.1: 13-18, Januari 2020

\title{
PERBAIKAN KUALITAS PROSES PRODUKSI DI UKM KERIPIK SINGKONG KABUPATEN MALANG
}

\section{Improving the Quality of Cassava Chips Production Process in Malang Regency SME's}

\author{
Siti Asmaul Mustaniroh ${ }^{1,3}$, Ika Fransiska Tarigan, Jaya Mahar Maligan ${ }^{2,3 *}$ \\ 1) Jurusan Teknologi Industri Pertanian, FTP Universitas Brawijaya Malang \\ 2) Jurusan Teknologi Hasil Pertanian, FTP Universitas Brawijaya Malang \\ 3) Pusat Studi Pengembangan Pangan Lokal, Universitas Brawijaya Malang \\ Jl. Veteran, Malang 65145 \\ *Penulis Korespondensi, Email: maharajay@gmail.com
}

\begin{abstract}
ABSTRAK
Salah satu produk unggul di Kabupaten Malang adalah singkong. Terdapat lima UKM dalam klaster UKM keripik singkong yang digunakan pada penelitian ini yang merupakan hasil dari 18 UKM. Tujuan penelitian ini untuk menentukan formula terbaik dalam meningkatkan kualitas keripik singkong di Kabupaten Malang, dimana hasil uji organoleptic akan dianalisis menggunakan metode Indeks Efektivitas (IE), kemudian hasil uji laboratorium dianalisis menggunakan metode Multiple Attribute (MA). Diperoleh formula terbaik pertama dari perhitungan IE dan MA adalah UKM Wijaya dengan kandungan kadar air $(7.66 \%)$, asam lemak bebas (0.55\%), dan keutuhan (93.35\%). Perbaikan dilakukan dengan dua metode penggorengan yaitu perlakuan pertama (suhu $197 \pm 2{ }^{\circ} \mathrm{C}$ 4-5 menit), perlakuan kedua (suhu $193 \pm 2{ }^{\circ} \mathrm{C}$ 5-6 menit). Setelah dilakukan perbaikan pada proses penggorengan didapatkan formula terbaik pada perlakuan pertama dengan nilai kadar air $4.54 \%$, asam lemak $0.03 \%$ dan persen keutuhan $95.05 \%$ yang memenuhi SNI.
\end{abstract}

Kata Kunci: Keripik singkong, Perbaikan kualitas, Proses penggorengan

\section{ABSTRACT}

One of the superior products in Malang Regency is cassava. There are five SMEs in the cluster of cassava chips SMEs used in this study which are the results of 18 SMEs. The purpose of this study was to determine the best formula for improving the quality of cassava chips, where the results of the organoleptic test would be analyzed using the Effectiveness Index (IE), then the laboratory test results using the Multiple Attribute (MA). The first best formula obtained from IE and MA calculations was UKM Wijaya with water content (7.66\%), free fatty acids (0.55\%), and wholeness (93.35\%). Quality improvement was done with two frying methods, the first treatment (temperature $197 \pm 2^{\circ} \mathrm{C}$ 4-5 minutes), and the second treatment (temperature $193 \pm 2^{\circ} \mathrm{C}$ 5-6 minutes). After improvements process, the best formula is obtained in the first treatment with a water content value $4.54 \%, 0.03 \%$ fatty acids, and $95 \%$ wholeness.

Keywords: Cassava chips, Quality improvement, Frying process

\section{PENDAHULUAN}

Pengolahan singkong menjadi keripik singkong di Kabupaten Malang telah banyak dilakukan oleh Usaha Kecil Menengah (UKM). Menurut Badan Pusat Statistik (BPS) Kabupaten Malang (2017), produktivitas singkong di Kabupaten Malang pada tahun 20132016 terjadi penurunan tetapi masih dapat memenuhi kebutuhan UKM keripik singkong yang ada di Kabupaten Malang. Jumlah UKM keripik singkong di Kabupaten Malang 
terdapat 18 UKM. Berdasarkan penelitian Astrianti (2017), terdapat klaster UKM keripik singkong yang terdiri atas 5 UKM yang eksis memproduksi dengan skala kecil dan menengah. Klaster UKM dengan skala kecil terdiri atas UKM Wijaya, Dua Bawang, Pokmas Mandiri dan Langgeng Jaya Abadi dengan indikator kapasitas produksi, jumlah karyawan, dan pendapatan, sedangkan klaster UKM skala menengah yaitu UKM Pondok Tua atau Lumba-Lumba yang cenderung memiliki ukuran lebih besar dari pada skala kecil dengan indikator yang sama.

Pada klaster UKM keripik singkong di Kabupaten Malang memiliki kendala dalam proses standarisasi produk dikarenakan inkonsistensi kualitas produk yang dihasilkan. Lama waktu penggorengan, dan ketebalan yang berbeda-beda pada tiap proses produksi menjadi salah satu pemicu terjadinya perbedaan hasil yang diproduksi. Pada UKM keripik singkong Kabupaten Malang, lama waktu penggorengan dilakukan kurang lebih 3-5 menit dengan suhu minyak yang sangat panas sehingga tidak terdapat ketetapan atau standar waktu dan suhu yang ditentukan untuk proses penggorengan. Seperti yang diketahui bahwa kandungan zat gizi yang paling banyak ditemukan dari singkong adalah karbohidrat sebesar 34.7\% (Direktorat Gizi, 2013). Menurut Isworo dan Siti (2010), makanan berpati atau mengandung karbohidrat jika dimasak pada suhu yang tinggi atau lebih dari $120{ }^{\circ} \mathrm{C}$ dapat menghasilkan zat akrilamida atau yang disebut sebagai zat pemicu kanker. Oleh karena itu, perlu dilakukan perbaikan kualitas agar produk keripik singkong yang dihasilkan sesuai selera konsumen dan standar (SNI 01-4305-1996) yang telah ditetapkan, baik untuk UKM dengan teknologi modern maupun tradisional yang dapat memenuhi kebutuhan konsumen.

Strategi perbaikan kualitas proses produksi keripik singkong dilakukan dengan metode Indeks Efektivitas (IE) dan Multiple Attribute (MA). Menurut Nurani dan Sudarminto (2014), IE merupakan suatu metode yang digunakan untuk menentukan alternatif terbaik dari semua perlakuan berdasarkan hasil uji organoleptik yang telah dilakukan, sedangkan MA merupakan suatu metode yang digunakan untuk menentukan nilai bobot untuk setiap atribut, kemudian dilanjutkan dengan proses perankingan yang akan menyeleksi alternatif yang sudah diberikan. Menurut Muley (2010), MA digunakan untuk mencari alternatif optimal dari sejumlah alternatif pada beberapa kriteria tertentu. Keripik singkong yang baik juga harus memenuhi standar SNI meliputi kadar air, kandungan asam lemak bebas dan keutuhan atau keadaan fisik produk.

\section{METODE PENELITIAN}

\section{Desain Penelitian}

Penelitian ini merupakan penelitian eksperimental, dimana tujuan penelitian eksperimental menurut Sugiyono (2017) adalah untuk mencari pengaruh perlakuan tertentu terhadap perlakuan yang lain dalam kondisi terkendali. Tahapan penelitian ini meliputi penentuan sampel, uji penerimaan konsumen I, uji laboratorium I, penentuan formula terbaik pertama, perbaikan proses, uji penerimaan konsumen II, uji laboratorium II dan penentuan formula terbaik kedua. Berikut adalah tahapan pada penelitian ini:

\section{a. Penentuan Sampel}

Populasi yang digunakan dalam penelitian yakni populasi yang berada dalam klaster yang terbentuk sebanyak 5 UKM keripik singkong. Sampel responden (uji penerimaan konsumen) diambil sebanyak 30 responden secara acak (random sampling). Responden yang digunakan pada penelitian ini adalah responden semi-terlatih. Pemilihan responden menggunakan kriteria bahwa responden mengetahui dan setidaknya pernah mengkonsumsi keripik singkong minimal satu kali.

\section{b. Pengujian Penerimaan Konsumen I}

Penentuan formula terbaik pertama dilakukan dengan uji penerimaan konsumen pada parameter organoleptik keripik singkong meliputi warna, aroma, kenampakan dan tekstur. Hasil uji penerimaan konsumen ini akan dianalisis menggunakan metode indeks efektivitas (Mulyadi dkk. 2014). 


\section{c. Pengujian Laboratorium I}

Tahapan selanjutnya adalah uji laboratorium sampel keripik singkong, meliputi uji kadar air, asam lemak bebas dan persen keutuhan sesuai SNI 01-4305-1996. Hasil uji laboratorium akan dianalisis menggunakan metode multiple attribute (Zeleny, 1982)

\section{d. Penentuan Formula Terbaik Pertama}

Formula terbaik pertama diperoleh dari integrasi hasil analisis indeks efektivitas dan hasil analisis multiple atribut (Mustaniroh dkk. 2019).

\section{e. Perbaikan Proses}

Perbaikan proses yang dilakukan akan ditentukan berdasarkan pendekatan analisis control point yakni dengan mengidentifikasi titik kendali proses produksi keripik singkong, dimana akan dipilih titik kendali proses yang paling mempengaruhi hasil uji organoleptik atau uji laboratorium sampel keripik singkong (Mustaniroh, dkk. 2019). Setelah didapatkan titik kendali yang diinginkan maka akan dilakukan pembuatan produk sesuai dengan perbaikan proses pada titik kendali tersebut.

\section{f. Uji Penerimaan Konsumen II}

Langkah selanjutnya adalah melakukan uji penerimaan konsumen pada produk yang dihasilkan setelah perbaikan proses meliputi warna, aroma, tekstur dan kenampakan.

\section{g. Uji Laboratorium II}

Sampel hasil perbaikan proses juga dianalisis laboratorium meliputi uji kadar air, asam lemak bebas dan persen keutuhan

\section{h. Penentuan Formula Terbaik Kedua}

Formula terbaik kedua diperoleh dari integrasi hasil analisis indeks efektivitas dan hasil analisis multiple attribute untuk sampel hasil perbaikan proses (Mustaniroh dkk. 2019)

\section{HASIL DAN PEMBAHASAN}

\section{Profil Klaster UKM Keripik Singkong}

Di Kabupaten Malang terdapat 5 UKM keripik singkong yang masih produktif dan bersedia untuk dilakukan penelitian di beberapa kecamatan yakni Kecamatan Turen, Kalipare hingga Singosari. Umumnya dana investasi awal didapatkan dari modal pribadi dan pinjaman pihak lain. Singkong didapatkan langsung dari petani maupun pengepul. Pemafaatan singkong untuk produk keripik singkong diharapkan dapat meningkatkan konsumsi masyarakat terhadap singkong. Objek yang digunakan dalam penelitian ini ada 5 UKM keripik singkong di Kabupaten Malang yang terbagi menjadi dua klaster yaitu klaster besar dan klaster kecil. Menurut Austin (1981), usaha mikro kecil dan besar (UMKM) mengacu pada kriteria yang digunakan BPS yang menggolongkan usaha berdasarkan jumlah tenaga kerjanya. Usaha kecil adalah usaha yang memiliki pekerja 5-19 orang dan usaha menengah memiliki pekerja 20-99 orang. UKM yang tergolong ke dalam klaster besar adalah UKM Pondok Indah atau Lumba-Lumba (E4) dengan jumlah pekerja 99 orang, sedangkan UKM yang termasuk klaster kecil diantaranya adalah UKM Dua Bawang (E1), Langgeng Jaya Abadi (E2), UKM Pokmas Mandiri (E3) dan UKM Wijaya (E5).

\section{Pengujian Penerimaan Konsumen I}

Responden yang digunakan berjumlah 30 orang yang merupakan responden agak terlatih. Pemilihan responden tersebut berdasarkan kriteria bahwa responden tersebut mengetahui keripik singkong dan setidaknya pernah mengkonsumsi keripik singkong minimal 1 kali. Penentuan hasil analisis indeks efektivitas berdasarkan rerata nilai produk tertinggi (Mulyadi dkk., 2014). Produk terbaik pada klaster UKM keripik singkong berdasarkan uji penerimaan konsumen adalah UKM Wijaya. parameter yang paling dipentingkan dalam memilih suatu produk adalah kenampakan dengan rerata sebesar 0.31 
(skor tertinggi). Kenampakan adalah hal utama yang akan dilihat oleh konsumen ketika memilih suatu produk. Menurut Herjanto (2008), kenampakan menunjukkan daya tarik suatu produk yang membedakannya dengan produk lain secara sepintas. Ketika kenampakan yang diberikan oleh suatu produk lebih menarik dari produk lain maka konsumen akan memilih produk yang memiliki kenampakan lebih yang lebih bagus dan menarik.

\section{Pengujian Laboratorium I}

Penentuan formula terbaik pertama juga dilakukan dengan uji laboratorium. Uji laboratorium digunakan untuk mengetahui kandungan mutu dalam bahan pangan (Motarjemi et al., 1996). Hasil uji laboratorium dianalisis dengan metode multiple attribute. Penentuan multiple attribute berdasarkan jarak kerapatan minimum. UKM sebagai formula terbaik yang memiliki jarak kerapatan minimum (2.92) adalah E1 (UKM Dua Bawang). Keripik singkong tersebut mengandung kadar air sebesar $8.50 \%$, asam lemak bebas sebesar $0.80 \%$ dan keutuhan sebesar $84.10 \%$. Namun hasil perhitungan indeks efektivitas dan perhitungan multiple attribute menghasilkan formula terbaik dari UKM yang berbeda. Hasil indeks efektivitas menunjukkan bahwa formula terbaik berdasarkan uji penerimaan konsumen adalah E5 (UKM Wijaya). Oleh karena itu, akan dilakukan integrasi antara 2 UKM dengan metode indeks efektivitas untuk UKM E1 dan UKM E5.

\section{Penentuan Formula Terbaik Pertama}

Hasil analisis indeks efektivitas akan diintegrasikan dengan hasil multiple attribute untuk menentukan formula terbaik pertama. Diantara 2 UKM keripik singkong yang memiliki nilai produk (Np) tertinggi adalah E5 (UKM Wijaya) yang merupakan formula terbaik pertama yang didapatkan berdasar analisis indeks efektivitas \& multiple attribute. Keripik Singkong tersebut mengandung kadar air sebesar $7.66 \%$, asam lemak bebas sebesar $0.55 \%$ dan persen keutuhan sebesar $93.35 \%$.

\section{Perbaikan Proses}

Perbaikan proses yang dilakukan adalah proses penggorengan keripik singkong. Pada proses penggorengan, dilakukan 2 perlakuan yang pertama adalah perlakuan penggorengan dengan suhu $197 \pm 2{ }^{\circ} \mathrm{C}$ dengan lama waktu 4-5 menit. Menurut Fetuga et al. (2014), peningkatan waktu atau suhu dapat mengurangi kandungan kadar air pada suatu produk. Perlakuan kedua adalah penggorengan dengan suhu $193 \pm 2{ }^{\circ} \mathrm{C}$ dengan lama waktu 5-6 menit. Perbaikan ini didasarkan pada hasil uji laboratoirum yang menunjukan bahwa terdapat parameter yang belum sesuai dengan SNI yakni parameter kadar air, untuk itu perlu dilakukan penambahan lama waktu penggorengan (perlakuan I) dan penurunan suhu penggorengan untuk mencegah terjadinya kenaikan kandungan asam lemak bebas (perlakuan II). Kedua perlakuan tersebut dilakukan untuk menurunkan kandungan kadar air pada keripik singkong. Menurut Asgar dkk. (2011), semakin lama proses penggorengan, maka semakin tinggi kadar air yang menguap sehingga kadar air yang tersisa semakin sedikit.

\section{Pengujian Penerimaan Konsumen II}

Penentuan formula terbaik kedua berdasarkan uji organoleptik dari UKM Wijaya sebagai formula terbaik pertama. Hasil uji penerimaan konsumen dapat dilihat pada Tabel 1.

Tabel 1. Hasil Penerimaan Konsumen Setelah Perbaikan Proses

\begin{tabular}{|c|c|c|c|}
\hline \multirow[t]{2}{*}{ Parameter } & Sebelum & \multicolumn{2}{|c|}{ Sesudah } \\
\hline & $\begin{array}{c}\text { Suhu } 197 \pm 2^{\circ} \mathrm{C} \text { dan } \\
\text { waktu } 3-4 \text { menit }\end{array}$ & $\begin{array}{c}\text { Perlakuan I } \\
\text { Suhu } 197 \pm 2^{\circ} \mathrm{C} \text { dan } \\
\text { waktu } 4-5 \text { menit }\end{array}$ & $\begin{array}{c}\text { Perlakuan II } \\
\text { Suhu } 197 \pm 2^{\circ} \mathrm{C} \text { dan } \\
\text { waktu 5-6 menit }\end{array}$ \\
\hline Warna & 3.70 & 3.77 & $4.00^{*}$ \\
\hline Aroma & 3.43 & $3.87^{*}$ & 3.77 \\
\hline Kenampakan & 3.73 & $4.27^{\star}$ & 3.87 \\
\hline Tekstur & 3.53 & $4.33^{*}$ & 4.27 \\
\hline
\end{tabular}

${ }^{*}=$ nilai tertinggi pada perlakuan 
Berdasarkan Tabel 1, dapat diketahui bahwa perlakuan yang memiliki nilai terbaik dan paling disukai panelis adalah perlakuan I dengan suhu $197 \pm 2{ }^{\circ} \mathrm{C}$ dengan waktu 4-5 menit. Parameter yang meliputi warna, aroma, tekstur dan kenampakan mempengaruhi panelis dalam memilih suatu produk. Karena memiliki skor yang lebih tinggi dibandingkan dengan produk hasil perlakuan II maka dapat dikatakan bahwa responden lebih menyukai keripik singkong hasil dari perlakuan I. Hal ini dikarenakan penggorengan dengan suhu 197 $\pm 2{ }^{\circ} \mathrm{C}$ dengan lama waktu 4-5 menit mampu menghasilkan keripik singkong yang mendekati selera konsumen. Keripik singkong perlakuan I memiliki warna kuning muda, aroma yang khas dan tidak menyengat, tekstur yang lebih renyah dan kenampakan yang lebih menarik.

\section{Pengujian Laboratorium II}

Penentuan formula terbaik kedua juga berdasarkan uji laboratorium dari UKM Wijaya sebagai formula terbaik pertama. Hasil uji laboratorium dapat dilihat pada Tabel 2.

Tabel 2. Hasil Uji Laboratorium Setelah Perbaikan Proses

\begin{tabular}{|c|c|c|c|c|}
\hline \multirow[t]{2}{*}{ Parameter } & \multirow{2}{*}{$\begin{array}{c}\text { Sebelum } \\
\text { Suhu } 197 \pm 2^{\circ} \mathrm{C} \\
\text { dan waktu 3-4 } \\
\text { menit }\end{array}$} & \multicolumn{2}{|c|}{ Sesudah } & \multirow{2}{*}{$\begin{array}{c}\text { SNI } \\
01-4305-1996\end{array}$} \\
\hline & & $\begin{array}{c}\text { Perlakuan I } \\
\text { Suhu } 197 \pm 2^{\circ}-C \\
\text { dan waktu } 4-5 \\
\text { menit }\end{array}$ & $\begin{array}{c}\text { Perlakuan II } \\
\text { Suhu } 197 \pm 2^{\circ}=\mathrm{C} \\
\text { dan waktu 5-6 } \\
\text { menit }\end{array}$ & \\
\hline Kadar air (\%) & 7.66 & 4.54 & 4.13 & $<6.0$ \\
\hline $\begin{array}{l}\text { Asam Lemak } \\
\text { Bebas (\%) }\end{array}$ & 0.55 & 0.03 & 0.02 & $<0.7$ \\
\hline $\begin{array}{l}\text { Persen Keutuhan } \\
(\%)\end{array}$ & 93.35 & 95.05 & 91.2 & $>90$ \\
\hline
\end{tabular}

Berdasarkan hasil uji laboratorium dihasilkan peningkatan dari sebelum perbaikan proses. Hasil perbandingan uji laboratorium sebelum dan setelah dapat dilihat pada Tabel 2. Didapatkan formula terbaik kedua sebesar $2.93 \%$ yaitu pada perlakuan pertama (PI) dengan proses penggorengan menggunakan suhu $197 \pm 2{ }^{\circ} \mathrm{C}$ dengan waktu $4-5$ menit. Hasil laboratorium yang dihasilkan mengalami peningkatan kualitas pada ketiga indikator. Pada indikator kadar air didapatkan penurunan nilai dari 7.66 menjadi 4.54, dimana semakin kecil kadar air maka keripik dikatakan semakin baik. Menurut Herawati (2008), semakin besar kandungan air dalam keripik singkong maka daya simpan produk akan semakin rendah dimana kadar air sangat berpengaruh terhadap daya simpan produk. Kemudian indikator uji asam lemak bebas mengalami penurunan nilai dari 0.55 menjadi 0.03 , dimana semakin rendah kandungan asam lemak bebas maka produk akan semakin bagus. Menurut Chijindu dan Boateng (2008), mengatakan kandungan asam lemak bebas rendah menandakan bahwa kualitas produk semakin baik dan umur simpan produk semakin lama. Pada indikator keutuhan mengalami peningkatan nilai yaitu dari 93.35 menjadi 95.05.

\section{Penentuan Formula Terbaik Kedua}

Hasil indeks efektivitas diintegrasikan dengan hasil multiple attribute untuk menentukan formula terbaik kedua. Hasil indeks efektivitas menunjukkan bahwa perlakuan I suhu $197 \pm 2{ }^{\circ} \mathrm{C}$ dengan waktu 4-5 menit merupakan perlakuan terpilih berdasarkan nilai produk tertinggi. Hasil multiple attribute menunjukkan bahwa perlakuan I suhu $197 \pm 2{ }^{\circ} \mathrm{C}$ dengan waktu 4-5 menit juga merupakan perlakuan terpilih berdasarkan jarak kerapatan terendah. Kedua metode tersebut menghasilkan perlakuan terpilih sama, sehingga perlakuan I merupakan formula terbaik kedua.

\section{SIMPULAN}

Hasil penentuan formula terbaik pertama berdasarkan uji penerimaan konsumen (indeks efektivitas) dan uji laboratorium (multiple attribute) adalah UKM Wijaya. Hasil penerimaan uji konsumen yaitu warna (3.70), aroma (3.43), kenampakan (3.53), dan tekstur 
(3.73). Pada hasil uji laboratorium, indikator yang belum sesuai SNI adalah kadar air. Setelah dilakukan perbaikan proses, formula terbaik kedua adalah perlakuan I (suhu $197 \pm 2^{\circ} \mathrm{C}$ selama 4-5 menit) dengan hasil uji penerimaan konsumen yaitu warna (3.70), aroma (3.43), kenampakan (3.53), dan tekstur (3.73). Hasil laboratorium menunjukkan bahwa kadar air dan asam lemak bebas dan keutuhan sudah sesuai dengan SNI 01-43051996.

\section{DAFTAR PUSTAKA}

Asgar, A., Rahayu S.T., Kusmana M., dan Sofiari E. 2011. Uji Kualitas Umbi Beberapa Klon Kentang untuk Keripik. Jurnal Hortikultura. Vol. 21 (1): 51-59.

Astrianti, N. 2017. Strategi Pengembangan Usaha Kecil dan Menengah Produksi Keripik Singkong Dengan Integrasi Merode K-Means Clustering dan Fuzzy Analytical Hierarchy Process (FAHP) (Studi Kasus Pada UKM Keripik Singkong Di Kabupaten Malang). Skripsi. Teknologi Industri Pertanian Universitas Brawiajaya. Malang

Austin, J. E. 1981. Agroindustrial Project Analysis. The Hohn Hopkins UP. London

Badan Pusat Statistik. 2017. Statistik Produktivitas Singkong di Kabupaten Malang. Badan Pusat Statistik Kabupaten Malang.

Chijindu, E.N. dan Boateng B.A., 2008. Effect of nutritional content of processed cassava chips on development of prostephanustruncates (Horn). World Journal of Agricultural Sciences, 4(3): 404-408

Direktorat Gizi. 2013. Daftar Komposisi Bahan Makanan. Bhatara. Jakarta.

Fetuga, G., Ajayi, T. and Karim, O. 2014. Effect of Frying Temperature and Time on Composition and Sensory Quality of Sweet Potato Crisps. Journal A Research Article in AJRTC 11(1): 17-25

Herawati, H. 2008. Penentuan Umur Simpan Pada Produk Pangan. Jurnal Litbang Pertanian, 27(4): 124-126

Herjanto, E. 2008. Manajemen Operasi. Grasindo. Jakarta

Isworo, S. dan Siti, A. 2010. Analisis Akrilamida Pada Keripik dan Kudapan Goreng dari Umbi-Umbian. ISBN : 978.979.704.883.9

Motarjemi, Y., Kaferstein, G., Moy, S., and Miyagishima. 1996. Application of HACCP to Food Manufacturing: Some Considerations on Harmonization Through Training. Food Control 5: 131-139.

Muley, A. And Bajaj V. 2010. Application of Fuzzy Multiple Decision Making Method Solving by Interval Numbers. ISBN, 2(1): 1-5

Mulyadi, A. F., Susinggih, W., Ika A., dan Widelia I. 2014. Karakteristik Organoleptik Produk Mie Kering Ubi Jalar Kuning (Ipomea Batatas) (Kajian Penambahan Telur dan CMC). Jurnal Teknologi Industri Pertanian, 15(1): 25-36

Mustaniroh, S. A, Puspitasari, N. A dan Maligan, J. M. 2019. The Strategy for Improvement of Enting Geti Quality in Production Process with Fuzzy Analytical Hierarchy Process in Blitar Regency East Java. Jurnal Manajemen \& Agribisnis, Vol. 16 No. 1, March $2019: 97-109$.

Nurani, S. dan Sudarminto, S. 2014. Pemanfaatan Tepung Kimpul (Xanthosoma sagittifolium) sebagai Bahan Baku Cookies (Kajian Proporsi Tepung dan Penambahan Margarin). Jurnal Pangan dan Agroindustri, 2 (2): 50-58

Sugiyono. 2017. Metode Penelitian Kombinasi (Mixed Methods). Bandung: Alfabeta

Zeleny, M. 1982. Multiple Criteria Decision Making. McGraw-Hill. New York 